\title{
A case study on teaching of energy as a subject for $9^{\text {th }}$ graders
}

\author{
Sevim bezen, Celal bayrak and Işıl aykutlu \\ Department of Mathematics and Science Education, Hacettepe University, Ankara, TURKEY \\ For correspondence: sevimbezen@hacettepe.edu.tr
}

\begin{abstract}
This study aims to describe how energy subject is taught in $9^{\text {th }}$ grades. The study is designed as a descriptive case study with the participation of 3 physics teachers and 85 students. Data were obtained through observation, interviews, and documents, and they were analyzed through descriptive analysis method. In the observations made at the participating schools, it was revealed that the teaching process of energy subject was improved by general lecturing and hence students have incorrect or incomplete knowledge on the topic. In the study, it was determined that teaching of energy subject was enjoyable because it is mostly related to daily life and it includes interpretation-based questions; it was also determined, however, that students have difficulty comprehending the subject.
\end{abstract}

Keywords: Energy, physics education, physics education program, physics teacher.

\section{Introduction}

Scientific development of a society is possible only through science education. The content in science education, which has recently become the focal point of science and technology, has increased (Çolak, 2005). In teaching this content (or knowledge), teaching programs, which consists of studentappropriate and simplified lectures on science, are made use of. These programs are revised and updated in order to have the best possible education and learning; and it is indicated that these programs should be designed in accordance with constructivist learning theory and technological developments (Bagley \& Hunter, 1992; Limon, 2001; Martin, 1997; Sherman, 2000). In constructivist learning, old knowledge of students play an important role, and new knowledge is constructed by themselves with the guidance of the teacher (Hewson \& Hewson, 1983; Tobin \&Tippins, 1993). Physics education program, which includes constructivist learning theory in itself, was revised in 2013 , and this revised program was decided to be applied by degrees beginning with $9^{\text {th }}$ grade in 2013-2014. Outcomes in the teaching program were designed in such a way so as to allow students to make connections between what they've learned and daily life, to hone critical and analytical thinking skills, and to relate science with technology, environment, and society. Outcomes of energy subject within $9^{\text {th }}$ grade physics teaching program were also classified at the basic level, and the aim was for students to learn conceptually and operationally and to be able to apply their knowledge to new situations (Ministry of Education [MEB], 2013). It is known that energy is found to be difficult and incomprehensible by the students. Reasons for this can be listed as follows: students cannot relate the topics to daily life, they have difficulty in mathematical operations, the subject includes abstract concepts, and there are very few experimental applications within the subject (Duit, 1992; Ergin\& Sar1, 2013; Hoffman, 1990). It is known that energy is a concept that forms the basis for many topics in physics and it is a core subject of science education (Ellse, 1988; Köse, Bağ, Sürücü\&Uçak, 2006). Energy is an abstract concept that requires more thorough thinking compared to other concepts (Ogborn, 1990; Warren, 1983). In addition to being widely used within science education, such concepts as energy preservation and energy resources are used knowingly or unknowingly in daily life. For instance, people may talk about how their energy is exhausted even they haven't done any 
physical activity. Studies also indicate how students have misconceptions before they start learning about the energy subject (Driver \& Warrington, 1985; Gilbert \& Pope, 1986; Kesidou\&Duit, 1993; Küçük, Çepni\&Gökdere, 2005; Solomon, 1982; Tatar \&Oktay, 2007; Trumper\&Gorsky, 1993; Watts, 1983). Within this context, in this study, how the teaching applications on the subject of energy are realized and how they are reflected in the class environment will be thoroughly examined and evaluated based on the process. Thus, the aim is to reveal how the application of the subject of energy is handled and what problems are seen during the application process.

\section{Aim and Significance of the Study}

Energy as a subject, which is part of the $9^{\text {th }}$-grade physics education program, is highly significant especially with the advent of technology and science. Papadouris, Constantinou, and Kyratsi (2008) underline the importance of the teaching of physics on the grounds that it provides a basis for the interpretation and understanding of energy and physical events and that it plays a central role in such topics as energy source, distribution, use, fuel consumption, transport economy, and nutrition. Because energyis one of the concepts students have the most difficulty in understanding, it is seen that teaching of the concept has gained importance and more studies have been done on it (Stylianidou, Ormerod\&Ogborn, 2002). When literature is examined, it can be seen that studied determined that students have various misconceptions about energy because they think of energy as a concrete thing, they confuse force, power, and energy, they define energy as a kind of life force, and they assume that only moving objects would have energy (Kruger, 1990; Trumper, 1998; Trumper, Raviolo\&Shnersch, 2000). Moreover, it was determined that when defining energy, students use such expressions as smoke, expanding heat, light, and sound energy (Watts, 1983; Yuenyong\&Yuenyong, 2007). In a study on the teaching of energy by Kaper and Goedhart (2002), it was determined that teachers' focusing solely on kinetic and potential energy in terms of energy types poses a problem for the following learning levels. Kesidou and Duit (1993), Zain and Sulaiman (1998) and Solomon (1982) indicated that students have incomplete and incorrect knowledge about technological advances in energy, the storage of energy, its preservation, transformation, and energy conservation. In the same vein, they concluded that students have a misconception that they assume energy comes to an end after a certain amount of usage. However, it is seen that these studies were conducted mostly at primary schools. The fact that previous studies were mostly on primary schools and that the revised energy subject will be applied for the first time makes this study significant.

In this study, the aim was to evaluate the-new-physics-program-appropriate teaching of energy as a subject at three different Anatolian high schools. Students' views on the applications of the program, problems faced in the teaching of energy, methods, techniques and strategies utilized by teachers, and how teachers relate energy to daily life were determined and evaluated. Because there were students from three different class levels in the study, a comparison between students was also made. At the same time, teachers were also compared in terms of their roles in the teaching process. It is thought that this study will contribute to literature because the program will be applied for the first time in classes where the research will be done, and because students' views and reactions towards the energy subject are realized by making use of qualitative case study pattern based on the process. Moreover, the fact that how the teachers who are the applicators of the new physics program, which has been updated by taking into consideration the results of previous research, run the teaching and learning processes in accordance with the new physics program will be examined and evaluated based on the process is also significant. When all these points are taken into consideration, it is believed that data obtained at the end of this study would contribute to physics education and to the future applicators because the data would reveal the positive and negative aspects faced during the teaching of energy as a topic in the new physics program. Within this context, answers to the following questions were sought in accordance with the research problem of this study, namely, "How is the teaching of energy as a subject, which is taught at $9^{\text {th }}$ grade, realized in process?"

1. How does the learning process of energy as a subject in $9^{\text {th }}$ grade develop? 
2. What are the problems faced during the learning process of energy as a subject in $9^{\text {th }}$ grade?

3. How appropriate is the energy topic taught by teachers to constructivist learning theory?

4. What course materials and tools do teachers use in teaching energy as a subject?

5. What are students' views and approaches to energy as a topic in $9^{\text {th }}$ grade?

\section{Methodology}

This study is designed as a case study, which is one of the qualitative research methods. Within the context of case study, the detailed description and examination of a well-limited topic in class environment was realized (Creswell, 2013; Glesne, 2012; Yin, 2009). Moreover, because the $9^{\text {th }}$ grade physics education is newly installed, the research was done in an observation-based direct descriptive case study. Pattern of this study is holistic multiple case pattern. Classes in three different Anatolian high schools were examined holistically on their own and then comparisons among them were made.

\section{Study Group}

Study group of the research consists of three physics teachers teaching the $9^{\text {th }}$ grades at three different Anatolian high schools and a total of 85 students from these schools: 31 students from the first Anatolian high school (FAH), 24 from the Second Anatolian high school (SAH), and 30 from the third Anatolian high school (TAH). In determining the participants, various samplings were used (Ersoy, 2006). Within the scope of criterion sampling, which is one of the purposeful sampling methods, class level was determined to be $9^{\text {th }}$ grade and the schools to conduct the study at were determined to be Anatolian high schools, hence thoroughly detailed and rich data were obtained (McMillan, 2004; Yıldırım\&Şimşek, 2013). Moreover, because observation notes for each and every student could not be taken due to the high number of students in classes, internal sampling method was employed. Internal sampling denotes the possibility of selectingthe participants, the documents, and the time of the research in order to increase the number of important information for the research data. Thus, appropriate participants were selected by the researcher, and by putting emphasis on the documents whose validity is certain, rich data were obtained.

\section{Data Gathering Tools}

In addition to observation being the primary data gathering tool of the study, data gathering was also done via research blog, video recordings, and a form for determining students' views on the teaching of energy as a subject. In this respect, multiple data gathering tools were used in accordance with the aim of the study (Creswell, 2013; McMillan, 2004). In order to support the obtained data, semiconstructed interviews were conducted with the students. In order to ensure the validity of the data gathering tools, views of a total of nine people, 3 of whom are physics teachers, 5 of which are experts in physics education, and 1 in education sciences, were consulted. In addition, a pilot application was done with the participation of $329^{\text {th }}$ graders at an Anatolian high school, which starts teaching energy as a subject one month before the selected three Anatolian high schools. As a result of the pilot study, it was determined that the data gathering tools are sufficient in revealing how the teaching of energy as a subject is realized in process in $9^{\text {th }}$ grade.

\section{The Application}

The application was realized in eight weeks during the teaching of energy in the participating classes. The researcher began to attend the classes a couple of weeks before the start of the application so that she could become part of the class environment. The researcher gathered the data via participatory observation technique in class during the research. Classes were recorded on video, and the camera was immobilized in the most feasible part of the class, and the recording was done automatically. Semi-constructed interviews with the students were done one-by-one by recording the interview with a voice recorder, and they lasted 25-30 minutes. Interviews were conducted one week after the completion of the application, and were done with $20 \%$ of the total number of students in each class. In order to describe the situation in class, views of six students from each class were taken, and in 
determining who those six students will be was decided in terms of their willingness. Obtained data were recorded in separately named files in digital environment.

\section{Data Analysis and Interpretation}

Analysis of the data was realized in two phases, namely, during the data gathering process and at the end of the data gathering process. Data were examined with descriptive analysis method, and they were summarized and interpreted according to certain themes. In the study, direct quotations were frequently used in order to reflect the interviews or the viewpoints of the interviewed individuals (Ylldırım\&Şimşek, 2013). The originals of the data (video recordings, voice recordings, observation notes) and the data on the form which contains their transcribed version were compared by experts. Data obtained as a result of expert views were transferred to the digital domain, they were re-read and arranged. Then, it was decided as to under which themes the data would be gathered in order to have a logically and meaningfully arranged data (Ylldırım\&Şimşek, 2013). Themes were decided in accordance with the answers given under research questions. At this stage, the researcher consulted an expert; after working on the answers again a consensus was reached and reliability was established. Moreover, validity and reliability studies were done in order to determine the validity of the results of the study. In order to ensure validity, each phase of data gathering and analysis was indicated in detail, and each situation that took place during the study was recorded. In building and interpreting the data, objectivity was sustained, direct quotations were given in order to support the findings, and observation data were presented to the teachers. Observation data were recorded directly and without interruption, different data gathering tools were employed for data variation. Researcher's position during the process was constantly explained and data were transcribed objectively, reliability study of the research was done with an expert. In addition to these, such strategies as plausibility, transmissibility, consistency, and affirmation were used in order to ensure validity and reliability.

\section{Results}

\section{Findings Related to How the Teaching of Energy is Realized in $9^{\text {th }}$ Grade}

When the data obtained from participatory observation, video records, and researcher's diary were examined, it was determined that the teaching of energy was realized through different processes in the three Anatolian high schools that were used in this study and that teachers completed the teaching of the subject following a different order. Activities realized in the observed classes were given in detail in the following tables. Activities realized in the First Anatolian High School (FAH) can be seen in Table 1 .

Table 1.Activities Realized in Physics Classes at FAH

\begin{tabular}{|c|c|c|}
\hline $\begin{array}{l}\text { Anatolian } \\
\text { High } \\
\text { School }\end{array}$ & Date / Hour & Realized Activities \\
\hline$\sum^{\mathbb{2}}$ & $\begin{array}{l}\text { Date: } 14.03 .2014 \\
\text { Hour: } 13.00-13.30\end{array}$ & $\begin{array}{l}\text { - Reminding that lecture on energy will begin. } \\
\text { - Teaching the concept of work } \\
\text { - Giving students formulas and explaining units. } \\
\text { - } \quad \text { Putting emphasis on the concepts of positive work, } \\
\text { - negative work, and network. } \\
\text { - } \quad \text { Asking students to take down notes. } \\
\text { - Providing sample questions about the concept of work. }\end{array}$ \\
\hline & $\begin{array}{l}\text { Date: } 20.03 .2014 \\
\text { Hour: } 09.45-10.25 / \\
10.35-11.15\end{array}$ & $\begin{array}{l}\text { First Period } \\
\text { - Distributing exercise sheets on work, force, and energy. } \\
\text { - Solving the questions related to the concept of work in the }\end{array}$ \\
\hline
\end{tabular}


Second Period

exercise sheet.

- Continuing with the questions on the concept of work.

- Teaching the concept of force.

- Giving students formulas and explaining units

- Drawing a connection between work, force, and energy.

- Solving questions related to the concept of force in the exercise sheet.

Date: 21.03 .2014

Hour: $12.50-13.30$
- Continuing with the questions on the concept of force

- Warning students to listen carefully.

- Teaching the concept of efficiency.

- Completing the teaching of work, force, energy and efficiency.

- Briefing students about the subjects to be covered in the next week's physics exam.

Date: 27.03 .2014

Hour: 09.45-10.25

Date: 28.03 .2014

Hour: $12.50-13.30$

- Teaching the concept of energy.

- Teaching the concept of mechanical energy.

- Giving homework on energy types.

- Teaching the concept of kinetic energy.

- Drawing a connection between Kinetic Energy and work

- Solving questions from the secondary source

- Continuing with question solving from the secondary source.
- Teaching the concept of potential energy

- Drawing a connection between potential energy and work.

- Reminding students of the homework on energy types.

- Distributing among students the presentation homework on energy transformations.

- Giving a project homework to two students on energy resources.

- Teaching the concept of potential energy.

- Solving questions about potential energy.

- Checking students' homework on energy transformation.

- Students' presentation on energy transformation.

- Pair study on energy transformation.

- Teaching the effect of frictional force on mechanical energy.

- Solving questions on the effect of frictional force on mechanical energy.

- Teaching of the concept of energy preservation.

- Displaying a simulation.

Date: 11.04 .2014

- Student presentation on energy resources.

Hour: $12.50-13.30$

- Showing a video on nuclear energy.

Date: 17.04 .2014

Hour: 09.45-10.25
- Checking the homeworks.

- Solving interpretation-based questions on energy.

- Pinning students' project homework on energy resources on the bulletin.

- Students examining the pinned homework. 
In the classes at $\mathrm{FAH}$, the teacher mostly employed lecturing, problem solving, and question and answer techniques while teaching. The following dialogue about the non-renewable energy resources was given in below as an example to question and answer technique:

Teacher: Will non-renewable energy resources expire? What do you think?

Female student2: yes, they will. Ma'am, what will we do when that happens?

T: We will use renewable energy resources.

FS2: But we can use nuclear energy.

T: Nuclear energy is among the non-renewable energy resources. Moreover, it is costly and causes air pollution. Nuclear energy wastes are buried into the earth and covered with a heavy layer of lead. These wastes are harmful to nature.

Male Student 4: Ma'am, what comes from nature goes back to nature. Why would nuclear energy wastes harm the environment?

T: It is used; it is not the same as the one found in nature. Thus, it harms nature.

In order to reiterate the topic, the teacher chose to solve questions on board after the lecturing. During the lecture, a student asked the following question about the concept of force "Ma' am, the arrow on the $\vec{F}$ you have given is to the right, but you have said that there is a force to the left. Shouldn't it be whichever direction the arrow shows is where the force is?" which shows that students do not have knowledge about vectors and that this lack of knowledge is reflected to the topic of energy. Moreover, it was determined that during problem solving students could not make sense of what they have learned and that they face problems due to incorrect mathematical operations. During the process, with the help of a simulation, reiteration of the learned concepts was realized. Students were especially interested in the video shown in class about nuclear energy, which is a hot topic today. It can be said that the teacher employed different teaching methods and strategies by reiterating students' knowledge with visual presentation. It was seen that students were more motivated when they were asked to solve interpretation-based questions given to them during the last class.

Some of the expressions taken from the researcher's diary are as follows:

The teacher solved many questions in order to reiterate what students learned. Students also participated frequently. The students asked their teacher many questions, and they discussed the course material among themselves, thus helped one another. The teacher gave examples from daily life so that students become more motivated. The teacher made use of the board, pen, books, and exercise sheet as course tools.

Classes realized at the Second Anatolian High School (SAH) are given in detail in Table 2.

Table 2.Activities Realized in Physics Classes at SAH

\begin{tabular}{|c|c|c|}
\hline $\begin{array}{l}\text { Anatolian } \\
\text { High } \\
\text { School } \\
\end{array}$ & Date / Hour & Realized Activities \\
\hline$\frac{5}{\omega}$ & $\begin{array}{l}\text { Date: } 12.03 .2014 \\
\text { Hour: } 11.50-12.15\end{array}$ & $\begin{array}{l}\text { - } \quad \text { Getting smart board ready for use. } \\
\text { - } \quad \text { Warning students to be quiet. } \\
\text { - } \quad \text { Teaching the concept of work. } \\
\text { - } \quad \text { Mentiong students formulas and explaining units } \\
\text { - } \text { Terk. } \\
\text { - } \quad \text { Asking studentionship between energy and } \\
\text { - Solving sample questions about the concept of work. } \\
\text { - } \quad \text { Lecturing on the effect of friction on work. }\end{array}$ \\
\hline & $\begin{array}{l}\text { Date: } 19.03 .2014 \\
\text { Hour: } 11.35-12.15\end{array}$ & $\begin{array}{l}\text { - Getting smart board ready for use. } \\
\text { - Asking students about the material they learned in } \\
\text { the previous course. }\end{array}$ \\
\hline
\end{tabular}


- Continuing with the solution of work-related questions.

- Teaching the concept of force.

- Giving students formulas and explaining units

- Solving questions on the concept of force.

- Expressing that the teaching of the concept of force is complete.

- Reminding that the following lecture will be on the concept of energy.

Date: 02.04.2014

Hour: 11.35-12.15
Date: 09.04.2014

Hour: 11.35-12.15
Date: 16.04 .2014

Hour: 11.35-12.15
- Getting smart board ready for use.

- Realizing the teaching of the concept of energy.

- Drawing a connection between the concept of work and energy.

- Talking about types of energy.

- Realizing the teaching of mechanical energy.

- Realizing the teaching of energy preservation.

- Realizing the teaching of energy transformation.

- Realizing the teaching of energy transference.

- Examining the effect of frictional force on energy.

- Realizing activities related to the material covered in class.

- Expressing that in the following class evaluation activities, question solving and the teaching of efficiency and energy resources will be realized.

- Getting smart board ready for use.

- Expressing that the previous class will be repeated.

- Checking whether students have the secondary source or not.

- Asking students to take down notes.

- Interrogating the concepts students learned in the previous class.

- Solving questions from the secondary source.

- Giving homework.

- Expressing that students will be asked to solve the homework problems on board and that this will have a weight in their performance evaluation.

- Continuing with solving problems.

- Reminding students not to forget their homework.

- Getting smart board ready for use.

- Checking whether students have the secondary source with them or not.

- Informing students that next class will continue with problem solving, teaching of the concept of efficiency, and will conclude with the teaching of energy resources.

- Making use of previous outcomes in problem solving.

- Solving the questions students could not in homework.

- Realizing the teaching of the concept of efficiency.

- Giving homework assignment from the secondary 


\section{source.}

- $\quad$ Reminding students that homework will be checked and that the new topic will be energy resources

Date: 18.04 .2014

Hour: $14.40-15.20$
- Getting smart board ready for use.

- Checking homework assignment.

- $\quad$ Telling students that they will watch a video on energy resources.

- $\quad$ Pausing the video to explain certain things.

In the classes at SAH, the teacher usually employed lecturing, problem solving and question and answer techniques while teaching. The teacher focused on concepts, formula and unit teaching in the first class, and students participated by asking questions. The teacher realized in time that she taught the concepts of direction wrong, and in order to give students the correct expression, she re-started the teaching of the subject during that course. Classes were conducted generally through asking questions to students and then through solving problems on board; and it was observed that problems solved during class were mostly at knowledge level. One example to such questions is as follows:

Example: When a $40 \mathrm{~N}$ force is applied to an unmoving object standing on a non-frictional horizontal plane, the work is $240 \mathrm{j}$. As such, how many meters does the object move?

The teacher solved the problems by including the students to the process; however, students were mostly passive audience in classes. Moreover, it was seen that most of the question are mathematicsbased, and that interpretation-based problems were given only as reiteration tools at the end of lectures (Figure 1).

\begin{tabular}{lcccc}
\hline Case & $\begin{array}{c}\text { Potential } \\
\text { Energy }\end{array}$ & $\begin{array}{c}\text { Kinetic } \\
\text { Energy }\end{array}$ & $\begin{array}{c}\text { Chemical } \\
\text { Energy }\end{array}$ & Heat \\
\hline $\begin{array}{l}\text { Energy stored in } \\
\text { battery }\end{array}$ & $\mathrm{X}$ & $\mathrm{X}$ & \\
\hline $\begin{array}{l}\text { Water falling } \\
\text { from the }\end{array}$ & $\mathrm{X}$ & & $\mathrm{X}$ \\
Waterfall & & & & \\
\hline $\begin{array}{l}\text { Jeothermal water } \\
\text { source }\end{array}$ & & $\mathrm{X}$ & $\mathrm{X}$ & \\
\hline Wind vane & & & $\mathrm{X}$ & \\
\hline Plants & $\mathrm{X}$ & $\mathrm{X}$ & & \\
\hline Fossil fuel & & & & \\
\hline $\begin{array}{l}\text { Plane moving on } \\
\text { air }\end{array}$ & $\mathrm{X}$ & $\mathrm{X}$ & & \\
\hline Food & & $\mathrm{X}$ & & \\
\hline Strained bow & & & & \\
\hline Steam-locomotive & & & & \\
\hline Moving car & & & & \\
\hline
\end{tabular}

Figure 1.Physics 9 Exercise Book Evaluation Questions (Şahin, 2013)

However, it was revealed that students have incomplete knowledge about the concepts taught during the first classes in which energy is the subject matter. This incompleteness was tried to be overcome by the teachers as they give visual and verbal examples. In addition to this, classes were conducted mostly through presentations reflected on board in the lab. The teacher lost too much time getting the smart board ready for use. In this respect, it is thought that wasting time is one of the disadvantages of smart boards. 
Here is an extract from the researcher's diary:

The teacher preferred showing a video during the last class. Giving importance to visuality in teaching the concept of energy, the teacher tried to give examples from daily life. In addition to these, it was determined that the teacher made use of a limited teaching tool and material during the teaching of the topic.

Classes realized at the Third Anatolian High School (TAH) are given in detail in Table 3.

Table 3.Activities Realized in Physics Classes at TAH

\begin{tabular}{|c|c|c|}
\hline $\begin{array}{l}\text { Anatolian } \\
\text { High } \\
\text { School } \\
\end{array}$ & Date / Hour & Realized Activities \\
\hline \multirow{5}{*}{$\sum_{5}^{\mathbb{S}}$} & $\begin{array}{l}\text { Date: } 03.04 .2014 \\
\text { Hour: } 11.30-12.00\end{array}$ & $\begin{array}{l}\text { - Reminding students that lecture on energy will } \\
\text { begin. } \\
\text { - Getting smart board ready for use. } \\
\text { - Teaching class through the prepared presentation. } \\
\text { - } \text { Reaching the vectors. } \\
\text { frictional force, energy, mechanical energy, kinetic } \\
\text { energy, gravitational force, potential energy, } \\
\text { work-energy change, and efficiency through the } \\
\text { presentation. }\end{array}$ \\
\hline & $\begin{array}{l}\text { Date: } 07.04 .2014 \text { / } 10.04 .2014 \text { / } \\
14.04 .2014 \\
\text { Hour: } 08.00-08.40 \text { / 11.20- } \\
12.00 \text { / 08.00-08.40 }\end{array}$ & $\begin{array}{l}\text { First Period } \\
\text { - Getting smart board ready for use. } \\
\text { - Problem solving about force, frictional force, } \\
\text { energy, mechanical energy, kinetic energy, } \\
\text { gravitational force, potential energy, work-energy } \\
\text { change, and efficiency } \\
\text { - Giving students homework assignment. } \\
\text { Second Period } \\
\text { - Getting smart board ready for use. } \\
\text { - Continuing problem solving about force, frictional } \\
\text { force, energy, mechanical energy, kinetic energy, } \\
\text { gravitational force, potential energy, work-energy } \\
\text { change, and efficiency }\end{array}$ \\
\hline & & $\begin{array}{l}\text { Third Period } \\
\text { - Cleaning the board } \\
\text { - Getting smart board ready for use. } \\
\text { - Continuing problem solving about force, frictional } \\
\text { force, energy, mechanical energy, kinetic energy, } \\
\text { gravitational force, potential energy, work-energy } \\
\text { change, and efficiency }\end{array}$ \\
\hline & $\begin{array}{l}\text { Date: } 17.04 .2014 \\
\text { Hour: } 11.20-12.00\end{array}$ & $\begin{array}{l}\text { - Getting smart board ready for use. } \\
\text { - } \quad \text { Realizing the teaching of energy resources. } \\
\text { - Talking about energy conservation. } \\
\text { - Energy balance: Realizing the teaching of nutrition } \\
\text { and physical activities. }\end{array}$ \\
\hline & $\begin{array}{l}\text { Date: } 21.04 .2014 \text { / } 24.04 .2014 \\
\text { Hour: } 08.00-08.40 / 11.20- \\
12.00\end{array}$ & $\begin{array}{l}\text { First Period } \\
\text { - Getting smart board ready for use. } \\
\text { - Problem solving about work, force, energy, energy } \\
\text { transformation and conservation, and energy }\end{array}$ \\
\hline
\end{tabular}




\section{resources. \\ Second Period \\ - Continuing problem solving about work, force, energy, energy transformation and conservation, and energy resources. \\ - Wrap-up session on energy.}

In the TAH, the teacher started the teaching of energy with vectors, which is not part of the program but which she thought is necessary to understand energy as a topic. She realized the teaching by employing question and answer technique, lecturing, and discussion method, and by making use of presentation and problem solving. It was determined that most of the questions used by the teacher were at the level of knowledge and comprehension. Students were generally passive listeners when the teacher conducted lecturing through presentation. Mistakes in the questions prepared by the teacher and the discrepancy between the question sentences and the given drawings were noticed by the students. This made us think that the teacher came to class without proper preparation. At the same time, it was determined that during the rather speedy problem solving session, students experienced mathematics-related difficulties and had incomplete knowledge about such concepts as force, work, and exchange, which were covered in previous classes. Lastly, the teacher mentioned energy balance, which was not covered at the other schools but is part of the teaching program. A dialogue between the teacher and students is given below:

FS5:Ma'am, wouldn't there be loss of heat energy due to friction? You said energy is always conserved but here heat energy is lost.

T: We think of that revealed heat as lost energy but it is not lost, it just gets out of our control.

MS20: Ma'am, we say energy is conserved, but when we increase both the kinetic and the potential energy of an object, total energy is not conserved. How is total energy conserved when both are increased?

T: This is a very good question, well done. Do you all agree with your friend?

FS16: Ma'am, energy is of course conserved here, in order to increase that object's energy, we give it energy. When energy decreases on the one hand, it increases on the other. In short, total energy does not change in my opinion, so I do not agree with that.

T: What your friend says is true. Is there anything you would like t ask on this topic?

Students (All class): (Silence)

Here is an extract from the researcher's diary entry:

The fact that the teacher made use of verbal questions had a positive impact on students' conceptual learning. Students participated more in the solution of the verbal questions. The teacher completed the teaching of the topic by making a revision at the remaining minutes of the class hour. The teacher made use only of the board and the marker again.

\section{Students' View on and Approach to Energy}

After the observation, students were asked the following question in order to determine their views on and approach to energy: (Table 4). "What are the positive or negative aspects of the teaching of energy as a subject compared to the teaching of other subjects?"

Table 4.Students' Views on the Learning Process of Energy as a Subject

\begin{tabular}{clcccc}
\hline & \multicolumn{2}{l}{ Student Answers } & \multicolumn{3}{c}{ Anatolian High Schools } \\
& \multicolumn{3}{l}{ FAH } & SAH & TAH \\
\hline \multirow{3}{*}{$\begin{array}{c}\text { Positive } \\
\text { Aspects }\end{array}$} & Related to daily life & $4(12,90 \%)$ & $11(45,83 \%)$ & $7(23,33 \%)$ \\
\cline { 2 - 6 } & You can make use of previous & $3(\% 9,67)$ & - & $1(\% 3,33)$ \\
\cline { 2 - 6 } & knowledge & & & \\
\cline { 2 - 6 } It has visual parts & $2(\% 6,45)$ & - & - \\
\hline
\end{tabular}




\begin{tabular}{|c|c|c|c|c|}
\hline & $\begin{array}{l}\text { Teaches energy resources and energy } \\
\text { preservation }\end{array}$ & $2(\% 6,45)$ & - & - \\
\hline & The topic is conceptual & $2(\% 6,45)$ & - & $2(\% 6,66)$ \\
\hline & $\begin{array}{ll}\begin{array}{l}\text { Having } \\
\text { questions }\end{array} & \text { interpretation-based } \\
\end{array}$ & $2(\% 6,45)$ & $3(\% 12,5)$ & $1(\% 3,33)$ \\
\hline & It is fun & $1(\% 3,22)$ & $3(\% 12,5)$ & $5(\% 16,66)$ \\
\hline & It has science in it & $1(\% 3,22)$ & - & - \\
\hline & It is easy to learn & $1(\% 3,22)$ & $6(\% 25)$ & $1(\% 3,33)$ \\
\hline & It increases interest in class & $1(\% 3,22)$ & - & $5(\% 16,66)$ \\
\hline & $\begin{array}{l}\text { It corrects our incorrect knowledge } \\
\text { stemming from daily life. }\end{array}$ & - & $1(\% 4,16)$ & - \\
\hline & You can have experimental activities. & - & - & $1(\% 3,33)$ \\
\hline \multirow{10}{*}{$\begin{array}{c}\text { Negative } \\
\text { Aspects }\end{array}$} & You don't have experiments & $5(\% 16,12)$ & - & - \\
\hline & The topic is abstract & $4(\% 12,90)$ & $2(\% 8,33)$ & $4(\% 13,33)$ \\
\hline & Formulas are difficult & $2(\% 6,45)$ & - & - \\
\hline & Teaching is not done well. & $1(\% 3,22)$ & - & - \\
\hline & The topic is boring & $1(\% 3,22)$ & - & $1(\% 3,33)$ \\
\hline & There are too many concepts to learn. & $1(\% 3,22)$ & - & $6(\% 20)$ \\
\hline & It is conceptually difficult to learn. & - & $2(\% 8,33)$ & $12(\% 40)$ \\
\hline & Resources used are insufficient & - & $1(\% 4,16)$ & - \\
\hline & It is a comprehensive topic & - & - & $8(\% 26,66)$ \\
\hline & $\begin{array}{l}\text { There are too many mathematical } \\
\text { operations. }\end{array}$ & - & - & $7(\% 23,33)$ \\
\hline
\end{tabular}

Data obtained as a result of the semi-constructed interviews conducted with the students from FAH, $\mathrm{SAH}$, and TAH in order to support the data are as follows:

MS22: If energy resources were at the beginning of the topic, then I think it would have got more attention from us as it is a recently debated topic, and our motivation would have been higher. The materials, techniques, methods, and tools employed by the teacher were appropriate but I think we were short on practical application. Within the scope of the topic, experiments should have been made and more interpretation-based questions should be given.

MS3: The topic was rather verbal. I liked the teaching of the topic through examples from daily life, and it was easier that way. Interpretation- based questions were difficult. Energy resources could have been given at the beginning of the topic. In fact, where energy comes from, how it is formed should have been the starting point of the discussion.

FS15:Itwasthesame. Theteachergave us a blandpresentationandshowed us a couple of images on thesmart board. But, thereshouldhavebeenexperiments. Therecouldhavebeen a fieldtripaboutenergyresources. Thesubjectwasverbal, andweliked it morethanothers, but it was not reallyeasy, it wasdifferentthanwhatweareusedto. Wefound it difficulttocomment on things, but it wasfun, andweunderstood it better. We had a chancetogetawayfromthemonotony of problem solving, and it washelpful. Lecturing, QEA, and problem solvingwereallfine but therecouldhavebeenmore. Course bookpreparedbytheMinistry of Educationcouldhave had moreexamplesbased on interpretationandfromdaily life.

Participated students were then asked "What are the difficulties (problems) you face when learning about energy, and how did you overcome them" (Table 5). It was seen that 6 students from FAH (19,35\%), 13 students from SAH $(54,16 \%)$, and 2 students from TAH $(6,66 \%)$ indicated that they had no difficulty learning energy. 
Table 5.Students' Views on the Difficulties They Face While Learning about Energy

\begin{tabular}{lccc}
\hline \multicolumn{1}{c}{ Student Responses } & FAH & Anatolian High Schools & TAH \\
\hline $\begin{array}{l}\text { I had difficulty because there are too many formulas } \\
\text { in the subject. }\end{array}$ & $9(\% 29,03)$ & $7(\% 29,16)$ & $17(\% 56,66)$ \\
\hline $\begin{array}{l}\text { I had difficulty understanding the subject because its } \\
\text { conceptual part is difficult. }\end{array}$ & $8(\% 25,80)$ & $4(\% 16,66)$ & $11(\% 36,66)$ \\
\hline $\begin{array}{l}\text { I could not understand all energy types because there } \\
\text { are too many of them. }\end{array}$ & $4(\% 12,90)$ & - & - \\
\hline $\begin{array}{l}\text { I had difficulty understanding energy } \\
\text { transformation. }\end{array}$ & & & - \\
\hline
\end{tabular}

When students were asked as to how they overcome these difficulties, they answered as follows:

MS4: I took extra classes at the private teaching institution.

Researcher: Why did you prefer a private teaching institution?

MS4: Because I like my teacher there and he teaches in the exact way I can understand the topics.

R: How is the teaching realized at school?

MS4: The teacher at school always lectures bearing in mind the general audience in class.

MS19: I constantly repeated the topic.

R: Did you do it with the help of your notebook?

MS19: Yes. The notebook, and then in the evenings on the internet, that's how I studied for the topic.

R: Has it ever occurred to you to ask your teacher about the things you could not comprehend?

MS19: No, becausewegothroughtopicsratherfast in class, andinstead of askingtheteacherabout theprevioustopics, I preferstudyingthemmyself.

As a third question, students were asked "Which secondary sources did you think would help you learning energy and how did you make use of them?" (Table 6).

Table 6.Students' Views on the Secondary Sources They Made Use of While Learning Energy

\begin{tabular}{lccc}
\hline \multicolumn{1}{c}{ Student Responses } & \multicolumn{2}{c}{ Anatolian High Schools } \\
& FAH & SAH & TAH \\
\hline Different secondary sources & $22(\% 70,96)$ & $15(\% 62,5)$ & $18(\% 60)$ \\
\hline Book by MoE (MEB) & $8(\% 25,80)$ & $8(\% 33,33)$ & $10(\% 33,33)$ \\
\hline Their physics notebook & $5(\% 16,12)$ & $2(\% 8,33)$ & $11(\% 36,66)$ \\
\hline Internet & $4(\% 12,90)$ & $1(\% 3,22)$ & $4(\% 13,33)$ \\
\hline Visual material & $1(\% 3,22)$ & - & - \\
\hline Encyclopedia & $1(\% 3,22)$ & - & - \\
\hline Scientific Journals & $1(\% 3,22)$ & - & $2(\% 6,66)$ \\
\hline Videos & $1(\% 3,22)$ & $2(\% 8,33)$ & $2(\% 6,66)$ \\
\hline Observations from daily life & $1(\% 3,22)$ & $2(\% 8,33)$ & - \\
\hline Documentaries & - & - & $1(\% 3,33)$ \\
\hline
\end{tabular}

Students expressed that they made use of various secondary sources, the most frequent of which are the book by MoE, their notebook, and different secondary sources, and that they made use of these sources especially when studying for the exam. When their reasons for resorting to secondary sources were examined, it was determined that students wanted to solve problems that would help them in the university entrance exam. 
The fourth question students were asked was "What kind of contribution did learning about energy make in your life (passing the course, transferring knowledge to daily life, drawing parallels with other topics, etc)?"

(Table 7).

Table 7.Students' Views on the Contribution of Learning About Energy to Them

\begin{tabular}{lccc}
\hline \multicolumn{1}{c}{ Student Responses } & \multicolumn{2}{c}{ Anatolian High Schools } \\
& SAH & SAH \\
\hline $\begin{array}{l}\text { To be able to understand energy-related } \\
\text { events in the universe more easily }\end{array}$ & $10(\% 32,25)$ & $11(\% 45,83)$ & $19(\% 63,33)$ \\
\hline Passing the course & $12(\% 38,70)$ & $8(\% 33,33)$ & $8(\% 26,66)$ \\
\hline $\begin{array}{l}\text { The fact that information on energy } \\
\text { resources can be used in daily life. }\end{array}$ & $4(\% 12,90)$ & $6(\% 25)$ & $3(\% 10)$ \\
\hline $\begin{array}{l}\text { The fact that information on energy } \\
\text { conservation can be used in daily life. }\end{array}$ & $5(\% 16,12)$ & $5(\% 20,83)$ & $3(\% 10)$ \\
\hline $\begin{array}{l}\text { To be able to understand other topics in } \\
\text { physics. }\end{array}$ & $5(\% 16,12)$ & $1(\% 4,16)$ & $3(\% 10)$ \\
\hline
\end{tabular}

As the fifth question, students were asked "When you think about the teaching process of other topics, what differences can you observe in the teaching of energy in terms of material, method, strategy, and technique?" 11 students from FAH (35,48\%), 10 students from SAH (41,66\%), and 15 from TAH (50\%) said that there is no difference by expressing that "Just like with the other topics, energy was taught by using the smart board and questions on the study sheets were solved. There was no difference despite the fact that it is an abstract topic. There was no difference but the topic could have been taught in a livelier and more entertaining manner, field trips could have been arranged, and the smart board could have been used more effectively. Experiments on energy could have been done because I personally like learing by doing things myself." Responses of students who think that there is a difference can be seen in Table 8.

Table 8.Students' Views on the Use of Materials, Techniques, Methods, and Strategies during the Teaching of Energy in Comparison to Other Topics

\begin{tabular}{lccc}
\hline \multicolumn{1}{c}{ Student Responses } & \multicolumn{3}{c}{ Anatolian High Schools } \\
& \multicolumn{1}{c}{ FAH } & SAH & TAH \\
\hline $\begin{array}{l}\text { More examples from daily life were } \\
\text { given }\end{array}$ & $5(\% 16,12)$ & $5(\% 20,83)$ & $2(\% 6,66)$ \\
\hline Video was shown & & & \\
\hline $\begin{array}{l}\text { Lecturing as a method was } \\
\text { frequently employed. }\end{array}$ & $11(\% 35,48)$ & $2(\% 8,33)$ & - \\
\hline No lab experiment was conducted. & $1(\% 3,22)$ & $5(\% 20,83)$ & $6(\% 20)$ \\
\hline $\begin{array}{l}\text { Interpretation-based questions } \\
\text { given. }\end{array}$ & $3(\% 9,67)$ & - & $3(\% 10)$ \\
\hline No visual material was used. & - & $2(\% 8,33)$ & $1(\% 3,33)$ \\
\hline
\end{tabular}

As the final question, students were asked, "What are the pieces of information you got from the teaching of energy that you can relate to daily life?" (Table 9). 
Table 9.Expressions Students Used to Relate Energy to Daily Life

\begin{tabular}{|c|c|c|c|}
\hline \multirow[t]{2}{*}{ Student Responses } & \multicolumn{3}{|c|}{ Anatolian High Schools } \\
\hline & $F A H$ & $S A H$ & TAH \\
\hline $\begin{array}{l}\text { I realized that everything in the universe has } \\
\text { energy. }\end{array}$ & $14(\% 45,16)$ & $10(\% 41,66)$ & $17(\% 56,66)$ \\
\hline $\begin{array}{l}\text { I became more conscious of energy } \\
\text { conservation. }\end{array}$ & $12(\% 38,70)$ & $8(\% 33,33)$ & $13(\% 43,33)$ \\
\hline $\begin{array}{l}\text { I learned that renewable energy resources are } \\
\text { recyclable. }\end{array}$ & $3(\% 9,67)$ & $5(\% 20,83)$ & $7(\% 23,33)$ \\
\hline $\begin{array}{l}\text { I learned that non-renewable energy } \\
\text { resources are harmful but less costly. }\end{array}$ & $3(\% 9,67)$ & $2(\% 8,33)$ & $3(\% 10)$ \\
\hline $\begin{array}{l}\text { I learned that static energy is found in } \\
\text { unmoving objects. }\end{array}$ & $2(\% 6,45)$ & - & $1(\% 3,33)$ \\
\hline I learned the reason for global warming. & - & $1(\% 4,16)$ & - \\
\hline
\end{tabular}

Some extracts from student interviews are given below as they support the findings obtained from the table:

FS8: I have started to think that whatever I take into my hands has energy. In short, after learning this topic, I have come to the realization that everything in the universe has energy.

FS2: I learned that I should use electricity or water more economically at home.

MS11: I learned why the trash bins on the streets have different compartments and what different energy resources exactly are.

As a result of the obtained findings and the interviews conducted with students, it can be said that the teaching of energy is helpful for students to have an idea about everyday occurrences.

\section{Discussion}

In this study, how energy as a subject was realized in the process in $9^{\text {th }}$ grade by means of research blog, video recordings, and a form for determining students' views on the teaching of energy as a subject. Moreover, semi-constructed interviews were used in order to support the data. In the study, how the process of teaching energy as a subject in $9^{\text {th }}$ grade develops, problems faced during the learning process, materials and course materials used in teaching, appropriateness of energy to constructivist learning theory, students approaches and views to energy were researched. In light of the findings, following results were reached, and the discussion of these results with findings in literature, and suggestions about similar research in the future were also given below.

In the updated physics program, it was emphasized that teachers should be guides and teachers should be active participants in the process. This expression shows that the program's target learning environment corresponds to constructive learning theory (MEB, 2013). At the end of the study, it was determined that teachers teach energy in accordance with constructive learning theory, that is to say, by drawing examples from daily life, by lecturing based on observation, and by enabling students to acquire critical interpretation skills. However, it was also seen that the expressed methods, techniques, and strategies were not enough in light of the objectives of the program and thus teachers cannot really realize a teaching that is appropriate to constructive learning theory (Gökçe, İşcan \& Erdem, 2012). As support for the results of this study, in literature it was indicated the reason behind this discrepancy between the application of the program and the objectives were listed as follows: students are not given the chance to experiment with the help of equipment either individually or as a group, students are not asked to reach knowledge themselves by giving them open-ended or semiopen ended questions in study sheets, students are not given an environment which would enable a scientific interaction among students, and students are not active participants in class (Kıllç, 2001). Moreover, it is thought that one of the teacher-related problems is that teachers refrain from applying 
constructivist program due to their lack of proficiency in this field and this creates an educational void (Ertem, 2013). Another finding in literature is that teachers' lack of proficiency in the field is one of the reasons for students' misconception (Sanders, 1993; Yip, 1998; Yağbasan \& Gülçiçek, 2003).

As a result of the observations done in the study, it was determined that teachers most frequently employ question-answer technique and problem solving method as lecturing methods. However, it was also revealed that the classes were not conducted as efficiently as possible (Kaptan, 1999; Okur \& Azar, 2011). It is believed that such teaching methods as demonstrations, in-class discussions, student presentations, field applications, field trips, and computer-aided teaching should be employed while teaching energy as a topic (Gerber, Brovey, \& Price, 2001). At the same time, it was also indicated by Ergin and Sarı (2013) that students would be more motivated towards the class when these classes are conducted with different teaching methods and that their learning would occur more meaningfully. It was also observed that student participation increased when teachers employ class discussion and group study.

In teachers' evaluation activities which they do in order to reinforce verbal lectures and to lay bare how students learn, what they learn, it was seen that teachers mostly prefer mathematics-based problems and that they usually end up solving these problems themselves. However, it was determined that in classes where teaching is fast-paced, students could not fully understand the topic and that they have incomplete knowledge in mathematical operations, which in return affect their learning in physics (Çınar, Teyfur \& Teyfur, 2006; Karakuyu, 2006; Kutluca \& Aydın, 2010; Tüysüz \& Aydın, 2009; Yangın \& Dindar, 2007). When the limited number of class hours in the programs is taken into consideration, it can be suggested that one solution to this problem is making mathematics and physics classes compatible with each other (Karakuyu, 2006). In addition, it was also revealed in the study that teachers make use of the smart board only as a board without using its other facilities; they make use of pen and paper, books, and exercise sheets. It can be claimed that because teachers take too long to get the board ready to use, the smart board has a negative effect on teaching (Becta, 2006; Cogill, 2001, qtd. in Sünkür, Arabacı \& Şanl1, 2012).

Another result obtained in the study is that when an environment is created in class for the discussion of energy sources, students tend to give their views related to nuclear energy, which is a recent hot topic in media. However, it was also revealed that students have many incomplete and incorrect knowledge about nuclear energy as they expressed that nuclear energy is a renewable energy source (Boyes \& Stranisstreet, 1990; Karagöz, 2007).

It can be suggested that a detailed chapter on nuclear energy be added to the coursebook in order to rectify students' and teachers' incorrect and incomplete knowledge on nuclear energy. In addition to this, it was also seen in the study that teachers tried to correct students' incomplete or incorrect knowledge, which were determined via the interpretation-based questions, by using verbal expressions. Teachers can employ such methods as analogies, conceptual change texts and concept maps instead of lecturing when they try to rectify students' misconceptions (Brown, 1994; Chambers \& Andre 1997; Dagher, 1994).

It was determined that students listen to the lecture more carefully when teachers solve the kind of problems that students may see at the university entrance exam. In a study by Ekici (2005), it was expressed that this attitude is related to students' desire to be successful at the university entrance exam. Moreover, by looking at the questions students ask to their teachers about the concept of force, it was determined that students don't know the subject of vector and thus have difficulty understanding energy due to their lack of knowledge on vectors. In the new physics program, one of the bacis principles is to teach students by enabling them to interpret the presented information with 
the knowledge they already have (MEB, 2013). When this principle is taken into consideration, it can be said that there is a discrepancy between the principles of the program and the array of subjects.

By looking at students' views, it was determined that there is no difference in the teaching process of subjects in terms of the used materials, techniques, strategy or tools, the only diffence being the more frequent employ of lecturing in the teaching of energy; it was determined that examples from daily life were given, interpretation-based questions were solved, labs were not used, no visual material was brought to class and video presentations should be employed. However, as Karakış (2006) indicated in her study, it was revealed that teachers do not break their routines and they ignore individual difference, and thus they realize a monolithic teaching. It is believed that teachers should not let students turn into passive observers in class, and they should teach the subjects byemploying appropriate methods, techniques, and strategies that would take students' individual differences into consideration and would be student-centered (Hynd, 2001; Karadağ et al., 2008; Peers, Diezmann, \& Watters, 2003). Moreover, it was determined that students experience difficulty due to the fact that the subject is both conceptual and it includes too many formulas. It is known that conceptual learning is difficult as it needs constantly to be supported by daily observations (Vosniadou, 1999). It was seen that students try to overcome this problem by attending lectures at private institutions, constantly repeating the subjects, and by referring to different secondary sources. Another result of the study was that students prefer to refer to a secondary source other than the one provided by the Ministry of Education. It was determined that students prefer something other than their course book because they want to solve problems and questions that they would face at the university entrance exam (Altun, Arslan \& Yazgan, 2004). In addition to all these, it was determined that interpretation questions were preferred as they require no pen or paper, and that these questions increase students' interest in class and that they are easier than questions which require mathematical operations. As international exams such as TIMMS and PISA also have questions based on interpretation, it can be suggested that more importance should be given to interpretation-based questions which would help the improvement of students' success and their comprehension of subjects and concepts (Karamustafaoğlu \& Sontay, 2012).

Lastly, it was determined that students realized that everything in the universe has an energy, that they have become more conscious about energy preservation, that they have knowledge about energy sources, that kinetic energy can be found in immobile objects, and that they have learned the reason behind global warming (Ünal, 2011). However, it is believed that acquisitions should be added in order for students to be more conscious and knowledgeable, and this means that class hours should be increased (Tanriverdi, 2009). Moreover, it was seen that students have comprehended other subjects in the physics education program more thoroughly due to the teaching of energy as a subject. Thus, it can be seen that energy is related to other subjects. In their study, Jin and Anderson (2012) determined that in addition to being related to other subjects in physics, energy is a concept that brings together many different disciplines.

\section{Conclusions}

After the completion of this study, it is thought that knowledge students acquire at class should be permanent since the real aim of education is to provide students with the knowledge that would help them sustain their own lives. Physics is generally considered to be a difficult class and it is also known that it is difficult to teach energy in a permanent and meaningful way as it contains abstract concepts. Moreover, students' previous knowledge and the incorrect information they acquire during the teaching of the subject results in students having misconceptions. In order to prevent this and provide a meaningful and permanent learning, students' previous notions should be questioned and teaching should be carried out in accordance with the teaching program. In this study, how energy as a subject is taught in process was described and suggestions as to how it should be conducted were 
given in the discussion section. It is believed that determining especially teacher-related problems would contribute to the future of teaching.

This study is limited to the energy topic taught at $9^{\text {th }}$ grade. It is believed that expanding this study to other topics covered within the physics program, which began to have been gradually run since 20132014 academic year, would be helpful to literature, to teachers, and to students.

\section{Acknowledgements}

This study was based on Sevim Bezen's master's thesis.

I would like to thank Assist. Prof. Dr. Isil Aykutlu for her invaluable contribution to my thesis and to this study.

\section{References}

Altun, M., Arslan, Ç. ve Yazgan, Y. (2004). Lise matematik ders kitaplarının kullanım şekli ve sıklığı üzerine bir çalışma [A study on thewaysand how frequentlyhighschoolmathematicscoursebooksareused]. Journal Of UludagUniversityFaculty Of Education, 17(2), 131-147.

Bagley, C., \& Hunter, B. (1992). Restructuring, constructivism, and technology: Forging a new relationship. Educational Technology, 22-27.

Boyes, E., \& Stanisstreet, M. (1990).Pupils' ideas concerning energy sources.International Science Education, 12(5), 513-529.

Brown, D. E. (1994).Facilitating conceptual change using analogies and explanatory models.International Journal of Science Education, 16(2), 201-214.

Chambers, S. K., \& Andre, T. (1997).Gender, prior knowledge, interest and experience in electricity and conceptual change text manipulations in learning about direct current.Journal of Research in Science Teaching, 34(2), 107-123.

Creswell, J. W. (2013). Qualitative inquiry and research design. Choosing among five approaches (3rd edition.). Thousand Oaks, CA: Sage.

Çınar, O., Teyfur, E. veTeyfur, M. (2006).Primary school teachers and administrators' views about constructivist education approach and programs.Inönü University Journal Of The Faculty Of Education, 7(11), 47-64.

Çolak, S. (2005).The effect of the teaching methots based on constructive learning approach on the successes in the subject of acids-bases and their conceptional variations, and the attitudes against the science lessons of eight class students primary school (Unpublished master's thesis). Gazi University, Ankara.

Dagher, Z. R. (1994). Does the use of analogies contribute to conceptual change?.Science Education, 78(6), 601-614.

Driver, R., \& Warrington, L. (1985).Students' use of the principle of energy conservation in problem situations.Physics Education, 20, 171-176.

Duit, R. (1992). Vorstellung und physiklernen [Conceivability and physics learning].Physik in der schule, 30, 282-285.

Ekici, G. (2005). Liseöğrencilerininöğrenciseçmesınavına (ÖSS) yöneliktutumlarınınbazıdeğişkenleraçısındanincelenmesi [High school students, Student Selection Exam (SSE ) analyzed in terms of the attitudes of some variables]. Hacettepe ÜniversitesiĔ̆itimFakültesiDergisi, 28, 82-90.

Ellse, M. (1988).Transferring not transforming energy.School Science Review, 69, 427-437.

Ergin S. ve Sarı, M. (2013). Fizik öğretmenlerinin öğrencilerin öğrenme stillerine uygun öğretim yapma düzeylerini belirleme üzerine bir çalışma [A study on determiningphysicsteachers' levels of realizing a teachingappropriatetostudents' learningstyles]. Fen Bilimleri Öğretimi Dergisi, 1(2), 81-96.

Ersoy, A. (2006). Technologically supported project-based learning applications at the fifth grade of primary school (Unpublished doctoral dissertation).Anadolu University, Eskişehir.

Ertem, H. Y. (2013). Fizik öğretmenlerinin yapılandırmacı öğretim programını uygulama yeterlilikleri üzerine bir durum çalışması [A casestudy on physicsteachers' proficiency in applyingconstructivistteaching program]. I. Ulusal Fizik Eğitimi Kongresi, Hacettepe Üniversitesi. Ankara, 12-14 Eylül.

Gilbert, J. K., \& Pope, M. L. (1986). Small group discussions about conceptions in science: A case study. Research in Science and Technology Education, 4, 61-76.

Glesne, C. (2012). Nitel Araştırmaya Giriş [IntroductiontoQualitativeResearch] (Ed: Ersoy, A. ve Yalçınoğlu, P.).Ankara: Anı Yayıncilik.

Gökçe, E.,İşcan, D. C. ve Erdem, A. (2012). Öğretmen adaylarının sınıf ortamında yapılandırmacılık yaklaşımına uygun çalışmalar gerçekleştirmesine ilişkin gözlemleri [Observations of pre-service teachers on realizingstudies in classappropriateforconstructivistapproach]. Journal Of Research in EducationandTeaching, 1(1), 111-127.

Hewson, M. G., \& Hewson, P. W. (1983).Effect of instruction using students' prior knowledge and conceptual changes strategies on science learning.Journal of Research in Science Teaching, 20(8), 731-743.

Hoffman, L. (Eds.) (1990). Naturwissenschaftlich-techischebildung und beruflicheorientierung (Teil A). Frauen imberuf.Förderungnaturwissenschaftlich-techischerfürbildungmädcheninderrealschule, 118-148. Köln: DeutscherInstuts-Verlang.

Hynd, C. (2001). Persuasion and its role in meeting educational goals. Theory into Practice, 40(4), 270-277. 
Jin, H., \& Anderson, C. W. (2012).A learning progression for energy in socio-ecological systems.Journal of Research in Science Teaching, 49(9), 1149-1180.

Kaper, W. H., \& Goedhart, M. J. (2002). “Forms of energy”, an intermediary language on the road to thermodynamics? Part II. International Journal of Science Education, 24(2), 119-137.

Kaptan, F. (1999). Fen Bilgisi Ö̆gretimi (TeachingScience). Ankara: Anı Yayıncılık.

Karadağ, E., Deniz, S., Korkmaz, T. veDeniz, G. (2008). Constructivist learning approach: A research on the scope of views of class teachers. Journal OfUludag University Faculty Of Education, 21(2), 383-402.

Karagöz, C. (2007). Attitutes and interests of pre-service chemistry teachers towards nuclear energy.Unpublished master's thesis, Gazi University, Ankara.

Karakış, Ö. (2006). The usage level of general learning strategies of students' having different learning styles at some of the higher studies institutions (Unpublished master's thesis).AbantİzzetBaysal University, Bolu.

Karakuyu, Y. (2006). Misconceptions in heat and temperature among high school students (Unpublished doctoral dissertation).SüleymanDemirel University, Isparta.

Karamustafaoğlu, O. ve Sontay, G. (2012). Bir TIMSS sinavinın ardından: TIMSS 2011'e katılan öğrenci ve uygulayıcı ögretmenlerin görüşleri [After a TIMMS Exam: Views of studentsandteacherswhoparticipated in 2011 TIMMS]. X. Ulusal Fen Bilimleri ve Matematik Eğitimi Kongresi. Niğde, 27-30 Haziran.

Kesidou, S., \&Duit, R. (1993).Students' conceptions of the second law of thermodynamics-an interpretive study.Journal of Research in Science Teaching, 30(1), 85-106.

Kılıç, G. B. (2001). Oluşturmacı fen öğretimi [ConstructionistScienceEducation].EducationalSciences: Theory\&Practice, 1(1), 9-22.

Köse, S., Bağ, H., Sürücü, A. veUçak, E. (2006).The opinions of prospective science teachers' about energy sources for living organisms.International Journal Of Environmental and Science Education, 1(2), 141-152.

Kruger, C. (1990). Some primary teachers ideas about energy.Physics Education, 25(2), 86-91.

Küçük, M., Çepni, S. veGökdere, M. (2005). Turkish Primary School Students Alternative Conception About Work, Power And Energy. Journal Physics Teacher Education Online, 3(2), 22-28.

Kutluca, T. ve Aydın, M. (2010). Difficulties secondary school mathematics teachers encountered during application of the new mathematics curriculum. Dicle University Journal Of Social Sciences Institute, 2(1), 11-20.

Limon, M. (2001). On the cognitive conflict as an instructional strategy for conceptual changes: A critical appraisal. Learning and Instruction, 36(4-5), 357-380.

Martin, D. J. (1997). Elementary science methods.A constructivist approach. Kennesaw State College, Delmar Publishers.

McMillan, J. H. (2004). Educational research: Fundematals for the consumer. (Fourth Edition).USA: Pearson Education, Inc.

Milli Eğitim Bakanlığı. (2013). Ortä̈̆gretim Fizik Dersi Öğretim Programı [Secondary School PhysicsTeaching Program]. Ankara: Talim ve Terbiye Kurulu Başkanlığı.

Ogborn, J. (1990). Energy, change, difference and danger.School Science Review, 72(259), 81-85.

Okur, M. \& Azar, A. (2011).Primary teachers' opinions about alternative measurement and assessment techniques used in science and technology course.Kastamonu Education Journal, 19(2), 387-400.

Papadouris, N., Constantinou, C.P., \& Kyratsi, T. (2008). Students' use of the energy model to account for changes in physical systems. Journal Of Research In Science Teaching, 45(4), 444-469.

Peers, C. E., Diezmann, C. M., \& Watters, J. J. (2003). Supports and concerns for teacher professional growth during the implementation of a science curriculum innovation. Research in Science Education, 33, 89-110.

Sanders, M. (1993). Erroneousideasaboutrespiration: Theteacherfactor. Journal of Research in ScienceTeaching, 30(8), 919-934.

Sherman. J. S. (2000). Science and science teaching. U.S.A.: The College of New Jersey.

Solomon, J. (1982). How children learn about energy or does the first law come first?. School Science Review, 63(224), 415-422.

Stylianidou, F., Ormerod, F., \& Ogborn, J. (2002). Analysis of science textbook pictures about energy and pupils' readings of them. International Journal of Science Education, 24(3), 257-283.

Sünkür, M., Arabacı, B. İ. veŞanlı, Ö. (2012). Elementary school students' views toward smart board practices (Malatya city sample). E-Journal of New World Sciences Academy NWSA-Education Sciences, 7(1),313-321.

Şahin, M. (2013). Fizik 9 soru kitabı [Physics 9 WorkBook]. Ankara: Plazma Yayıncılık.

Tanriverdi, B. (2009). Analyzing primary school curriculum in terms of sustainable environmental education.Education and Science, 34(151), 89-103.

Tatar, E. veOktay, M. (2007). Students' missunderstandings about the energy conservation principle: A general view to studies in literature. International Journal of Environmental \& Science Education, 2(3), 79-81.

Tobin, K., \&Tippins, D. (1993).Constructivism as a deferent for teaching and learning. In K. Tobin (Ed.), Thepractise of consiructivism in science education (pp. 3-21). New Jersey: Lawrence Erlbaum Associates.

Trumper, R., \&Gorsky, P. (1993). Learning about energy: The influence of prior knowledge, cognitive levels and closed mindedness. Journal of Research in Science Teaching, 30, 637-648.

Trumper, R. A. (1998).Longitudinal study of physics students' conceptions on energy in pre-service training for high school teachers.Journal of Science Education Technology, 7(4), 311-318.

Trumper, R., Raviolo, A., \&Shnersch, A. M. (2000). A cross-cultural survey of conceptions of energy among elemantary school teachers in training- empirical results from Israel and Argentina. Teaching and Teacher Education, 16, 697-714.

Tüysüz, C. ve Aydın, H. (2009).The elementary school science and technology teachers' perceptions toward to new science and technology curriculum.Gazi University Journal OfGazi Educational Faculty, 29(1), 37-54.

Ünal, S. (2011).Analysis of elementary secondary level students' knowledge and attitude about environment: Dikili district sample (Unpublished master's thesis). Balıkesir University, Balıkesir.

Warren, J. W. (1983). Energy and its carriers: A critical analysis. Physics Education, 18, 209-212. 
Watts, D. M. (1983).Some Alternative Views of Energy. DM Watts Physics Education, 18(5), 213-261.

Yağbasan, R. veGülçiçek, G. (2003).Describing the characteristics of misconceptions in science teaching.Pamukkale University Journal Of Education, 13, 110-128.

Yangin, S. ve Dindar, H. (2007).The perceptions of teachers about the change on elementary school science and technology curriculum. Hacettepe University Journal of Education, 33, 240-252.

Yıldırım, A. ve Şimşek, H. (2013). Sosyal Bilimlerde Nitel Araştırma Yöntemleri [QualitativeResearchMethods in SocialSciences].Ankara: Seçkin Yayıncılık.

Yin, R. Y. (2009). Case study research: Design and methods. (Fourth Edition). Thousand Oaks: Sage Publication.

Yip, D. Y. (1998). Teachers' misconceptions of the circulatory system.Journal of Biological Education, 32(3), 207-216.

Yuenyong, C., \& Yuenyong, J. (2007). Grade 1 to 6 thai students' existing ideas about energy. Science Education International, 18(4), 289-298.

Zain, M. N. A., \& Sulaiman, F. (1998). Physics students' conceptions of energy and technological development in energy. Renewable Energy, 14(1), 415-419. 